\title{
PEMBENTUKAN RUANG KOLEKTIF SEBAGAI LANSKAP KREATIF MASYARAKAT KAMPUNG KOTA DI KEBON KACANG
}

\author{
Nathanael Hanli ${ }^{1)}$, Fermanto Lianto ${ }^{2)}$ \\ 1) Program Studi S1 Arsitektur, Fakultas Teknik, Universitas Tarumanagara, nathanaelhanli@yahoo.co.id \\ 2) Program Studi S1 Arsitektur, Fakultas Teknik, Universitas Tarumanagara, fermantol@ft.untar.ac.id
}

\begin{abstract}
Abstrak
Abad ke-21 menjadi saksi atas transformasi perekonomian masyarakat kota di mana perkembangan suatu kawasan tak lagi ditentukan oleh keberadaan sumber daya fisik semata, melainkan juga ide dan pemikiran manusia sebagai katalis perkembangan ekonomi kreatif. Diversitas serta identitas yang membentuk citra suatu kawasan mengundang hadirnya individu dari berbagai komunitas yang berbeda, menciptakan lanskap kreatif sebagai third place di mana masyarakat kreatif dapat berinteraksi satu sama lain dan saling bertukar pikiran. Kelurahan Kebon Kacang sebagai permukiman kampung kota (first place) yang berbatasan dengan sentra bisnis dan perekonomian kota (second place) berkepadatan tinggi mendorong pemanfaatan ruang-ruang antara yang tersisa seperti bahu jalan dan lahan kosong sebagai third place bersifat informal yang diisi secara cair dan temporal oleh masyarakatnya, menjadikannya tak hanya sebagai wadah interaksi melainkan juga sarana berkreasi yang menghasilkan produk-produk lokal seperti kuliner hingga industri tekstil skala kecil. Melalui investigasi kawasan yang didasari oleh dua metode utama, yakni observasi lapangan dan kajian pustaka terhadap pembentukan ruang sosial di kampung kota sebagai third place, potensi karakteristik informal dalam pembentukan ruang antara sebagai lanskap kreatif di kawasan Kebon Kacang pun diangkat sebagai gagasan dalam perencanaan dan perancangan Ruang Kolektif Kebon Kacang yang bertujuan menghadirkan third place sebagai wadah interaksi, kreasi, dan promosi bagi seluruh lapisan masyarakat di Kelurahan Kebon Kacang.
\end{abstract}

Kata kunci: informal; kampung kota; Kebon Kacang; lanskap kreatif; ruang ketiga

\begin{abstract}
The turn of the $21^{\text {st }}$ century saw a transformation in urban society as the abundance of physical resources no longer serves as the sole determinant of a city's economic development, rather it is the human capital and the ideas produced which generate growth through the creative economy sector. The image of a city, engraved by diversity and distinctive local identity, engage with individuals from various communities, establishing a creative landscape as a third place where interaction between members of the creative class occurs. The neighbourhood of Kebon Kacang is known as a residential area which embraces the city-village typology (first place). Located next to the central business district and economic center of the city (second place), its inhabitants are forced to occupy negative spaces left in between the high density area of downtown Jakarta, such as sidewalks and empty lot, and overhauling them in a temporal and spontaneous manner into informal third places. Aside as a social space for the local residents, the informal third place of Kebon Kacang also function as a production house for a variety of local products, ranging from staple dishes to small scale textile industry. Through the synthesis process consisting of field observation and literature study regarding the formation of social space in urban kampung, the informal quality attributed to the creative landscape of Kebon Kacang serves as a foundation in the planning and design process of Kebon Kacang Collective Space.
\end{abstract}

Keywords: creative landscape; informal; Kebon Kacang; third place; urban kampung 


\section{PENDAHULUAN}

Jakarta tak ubahnya sebuah kampung kota yang menaungi aktivitas informal para penghuninya, bahkan tercatat lebih dari $70 \%$ penduduk kota Jakarta bekerja dalam sektor informal (Sihombing, 2001). Alih-alih seperti sebuah kota yang direncanakan secara terpusat, Jakarta nampak seperti kumpulan kampung yang dipadatkan secara organik oleh kolektivitas para penghuninya (McGee, 1991). Ruang kolektif tersebut muncul sebagai wadah sosial yang mengisi ruang negatif di sela-sela bangunan ataupun jalur pergerakan, sebagai third place dalam ruang di antara aktivtias formal pada first place dan second place. Bersamaan dengan monumen dan infrastruktur kota, ruang kolektif tersebut pun turut mengemban peran dalam pembentukan identitas kota Jakarta (Michiels, 2007).

Kehadiran kampung kota sebagai citra kota Jakarta tak pernah kehilangan relevansinya, bahkan kala Jakarta berkembang sebagai salah satu kota metropolitan terbesar di dunia. Melalui identitas budaya serta ruang sosial yang disediakannya, Jakarta telah bertransformasi menjadi suatu lanskap baru bagi kelompok masyarakat kreatif (creative class). Pada abad ke-21, pertumbuhan ekonomi suatu negara atau wilayah tak lagi bergantung pada bangunan, perusahaan, atauapun infrastruktur, melainkan dari kumpulan sumber daya manusia berkualitas yang bernaung di dalamnya (Glaeser, 2011).

Keahlian serta kreativitas manusia menjadi sumber daya utama pengerak perekonomian dunia. Sentralisasi sumber daya demi efisiensi dan produktivitas tak lagi menjadi tujuan utama dalam berdirinya sebuah kota, melainkan memancing pertukaran ide melalui interaksi antar insan kreatif (Jacobs, 1989). Dalam buku The Rise of Creative Class, Richard Florida mengungkapan bahwa setidaknya terdapat tiga aspek mendasar yang harus dipenuhi agar suatu kota atau kawasan dapat berkembang secara ekonomi melalui kehadiran masyarakat kreatif, yakni teknologi (technology), bakat (talent), dan keberagaman (tolerance) (Florida, 2012). Revolusi secara konstan hadir melalui teknologi mumpuni disertai kehadiran masyarakat kreatif dengan ambisi, kemampuan, serta ide-ide besar. Namun keberagaman, dalam segala aspek kehidupan kota, menjadi poin krusial dengan mempertemukan berbagai sudut pandang berbeda menjadi suatu generator kreativitas dan munculnya gagasan-gagasan baru.

Florida juga mengungkapkan aspek keruangan yang disebutnya sebagai aset teritorial (territorial assets) sebagai penunjang bagi keberadaan ketiga aspek sebelumnya. Aset teritorial menjelaskan bahwa terdapat tiga dimensi mendasar yang menyebabkan masyarakat kreatif menetap secara memusat dalam suatu kawasan tertentu, yakni apa yang ada (what's there), siapa yang ada (who's there), dan apa yang terjadi (what's going on).

Secara prinsip, kehadiran ruang sosial yang bersifat kreatif telah dipenuhi oleh keberadaan kampung kota di Jakarta melalui nilai-nilai keberagaman, fleksibilitas, otentitas, serta konektivitas yang dimilikinya. Masing-masing kawasan di kota Jakarta memiliki potensi unik tersendiri yang layak untuk diangkat sebagai lini terdepan bagi masyarakat dalam menghadapi perkembangan pesat yang terjadi di era globalisasi tanpa kehilangan identitas lokal serta semangat kebersamaan. Akumulasi dari keseluruhan nilai tersebut dapat ditemukan secara spesifik pada kawasan Kebon Kacang yang terletak pada di jantung perekonomian kota Jakarta.

Kelurahan Kebon Kacang di Jakarta Pusat mengemban fungsi ganda sebagai kawasan permukiman kampung kota berkepadatan tinggi (first place) dan sentra perekonomian dan pusat perbelanjaan (second place) yang dikemas dalam identitas lokal sebagai salah satu sentra industri tekstil terbesar, tak hanya di Indonesia melainkan juga di Asia Tenggara. Melihat kehadiran lanskap kreatif serta potensi industri tekstil lokal yang ada, tak ayal keberadaan third place sebagai ruang sosial yang bersifat informal dan cair ditengah padatnya pusat kota Jakarta dibutuhkan guna mengangkat taraf hidup masyarakat di kawasan Kebon Kacang, serta sebagai generator interaksi antar insan kreatif yang bersifat terbuka bagi seluruh kalangan masyarakat.

Kawasan Kebon Kacang sebagai lokasi strategis juga turut menggundang permasalahan tersendiri, yakni tingginya densitas kawasan yang tidak diimbangi dengan keberadaan ruang publik yang memadai, mengingat pusat perbelanjaan sebagai fasilitas rekreasi utama masyarakat di kawasan tersebut masih bersifat terbatas bagi kalangan tertentu, sehingga 
masyarakat pada akhirnya terdorong untuk memanafaatkan ruang-ruang negatif yang tersisa di antara padatnya kota sebagai ruang sosial.

Melalui pemanfaatan ruang sisa tersebut, muncul potensi berupa aktivitas informal yang diperkuat oleh morfologi kawasan sebagai kampung kota yang terbentuk secara organik, menghasilkan ruang antara yang tak terduga dan diisi secara spontan (placemaking) hingga pada akhirnya menciptakan suatu bentukan yang bersifat temporal sebagai wadah aktivitas yang dapat dinikmati oleh seluruh kalangan yang terlibat di dalamnya (Rubio, 1987).

Terdapat dua rumusan permasalahan yang dijawab melalui penelitian sebagai landasan bagi perancangan arsitektur di Kelurahan Kebon Kacang, yakni:

- Bagaimana peranan third place dapat menunjang aspek sosial-ekonomi dalam kehidupan masyarakat di kawasan Kebon Kacang?

- Bagaimana ruang sosial yang timbul secara informal seperti industri tekstil rumahan dan pedagang kaki lima dapat dikelola sebagai bagian dari lanskap kreatif di kawasan Kebon Kacang?

Dalam menjawab kedua rumusan masalah tersebut, penelitian ini diharapkan mampu menjawab dua tujuan utamanya, yakni menciptakan third place sebagai ruang publik yang mengakomodir terjadinya interaksi antar masyarakat di kawasan Kebon Kacang sebagai pelaku insan kreatif, serta mempertahankan citra unik kawasan melalui preservasi identitas Kebon Kacang yang diwadahi oleh third place sebagai sentra kreasi dan promosi bagi industri tekstil yang terbentuk atas budaya hidup masyarakatnya.

\section{KAJIAN LITERATUR}

Seiring dengan berkembangnya dinamika kehidupan manusia, konsepsi makna atas ruang pun berkembang sebagai manifestasi atas kebutuhan dan persepsi manusia secara sosial. Tak lagi kita membaca ruang melalui atribut fisik yang nampak dan terukur semata, kini ruang turut hadir dalam keseharian kita sebagai produk dari regulasi dan praktik sosial. Dalam bukunya, The Production of Space, Henri Lefebvre, seorang sosiolog dan filsuf asal Perancis, menggambarkan fenomena tersebut sebagai ruang absolut (yang mana memiliki wujud pasti, volume terukur, serta stabilitas) dan ruang abstrak (yakni suatu ruang yang regulasinya merupakan hasil inisiasi dari relasi sosial) (Lefebvre, 1974). Ruang secara abstrak merupakan suatu kompleksitas yang tersusun atas lapisan-lapisan konsepsi makna sosial yang timbul dalam aktivitas keseharian sekelompok manusia.

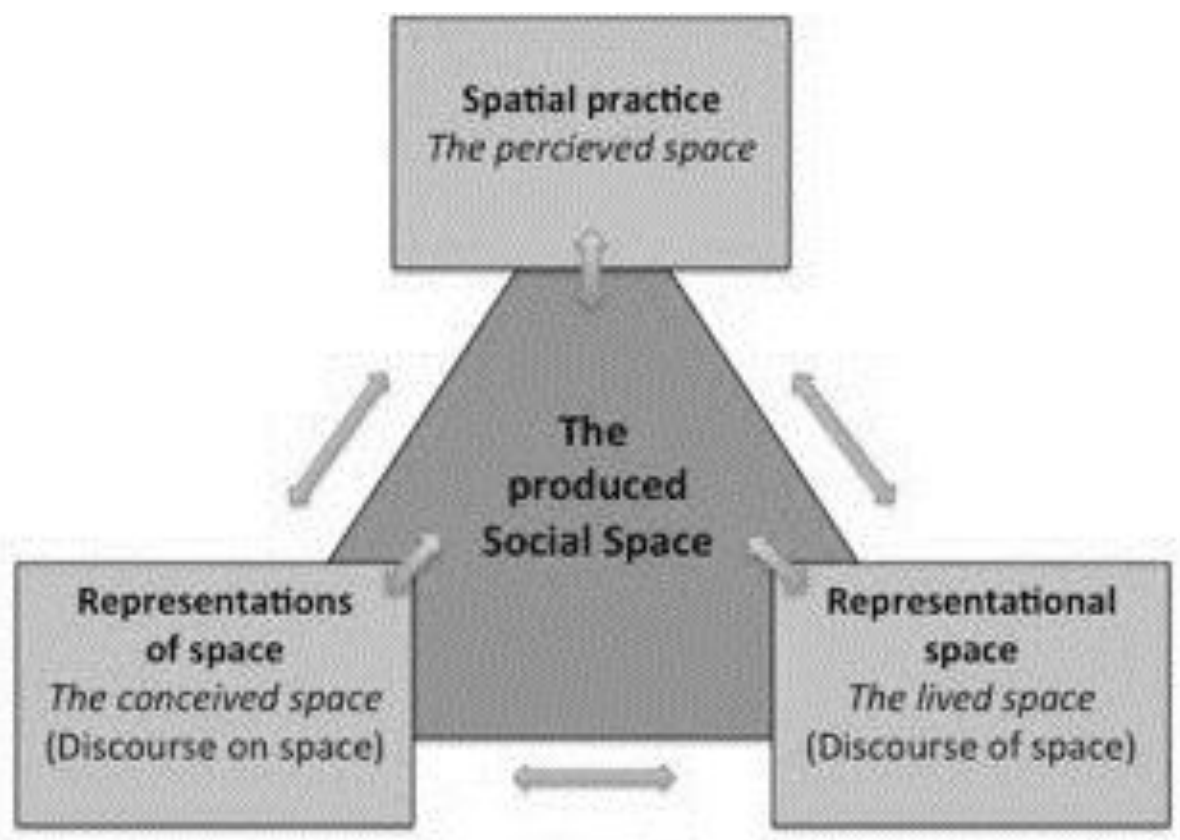

Gambar 1. Triade produksi ruang sosial oleh Henry Lefebvre Sumber: wordpress.com, diunduh 2 September 2019 
Lefebvre pun turut memformulasikan siklus produksi ruang secara sosial dalam suatu bentuk triade. Pertama-tama ialah praktek spasial (spatial practice), di mana konteks sosio-politik maupun karakter budaya disekeliling ruang membentuk persepsi manusia terhadap ruang tersebut (perceived space). Makna dan pembacaan atas suatu ruang kemudian membentuk suatu gagasan akan bagaimana ruang tersebut menjadi pantas untuk digunakan. Pada praktek spasial, ruang tidak hadir sebagai wujud nyata, melainkan berupa suatu gagasan, mitos, ataupun representasi dari sebuah ide. Selanjutnya, dalam representasi (representation of space) ruang pun diproduksi sebagai hasil perencanaan atau perancangan secara institusional oleh pihakpihak tertentu (conceived space). Representasi ini mewujudkan suatu formula akan bagaimana seharusnya sebuah ruang digunakan dan diregulasikan. Terakhir, ialah yang dianggap sebagai ruang sesungguhnya. Suatu ruang yang lahir melalui representasi mental dan pengalaman personal dari masing-masing entitas yang menghuninya (representational space). Seiring berjalannya waktu, ruang yang kita huni turut menimbun memori-memori yang terjadi didalamnya, maka tak ayal ruang representasi pun memiliki sifat monumental.

Lefebvre mengemukakan bahwa karakteristik monumental yang disebutkannya merujuk pada suatu simbol yang tak hanya memiliki satu makna (signified) melainkan kemungkinan yang tak terbatas (horizon of meaning) selayaknya sebuah karya seni seperti lukisan, aransemen musik, ataupun puisi yang dapat diinterpretasikan secara bebas oleh pembacanya. Kata "monitu", sebagai akar kata dari "monumental", dalam bahasa Latin memiliki artian untuk mengingatkan, rekoleksi atas memori, merujuk tidak pada wujud fisik yang monumental yang identik dengan stabilitas dan durabilitas, melainkan gagasan konseptual akan memori yang bersifat tidak tetap dan temporal.

Dalam ruang-ruang representasi (representational space) yang bersifat monumental tersebut ekspresi kolektif manusia pun muncul secara seutuhnya sebagai memori kolektif yang mendefinisikan ruang abstrak sekalipun kita tidak dapat mengukur ataupun merabanya secara fisik. Sejalan dengan nilai-nilai tersebut, ialah konsep weak architecture yang dikemukakan oleh Ignasi de Sola Morales Rubio. Dalam pandangannya tersebut, Rubio mengemukakan bahwa dalam konteks waktu masa kini, ruang dan waktu telah kehilangan stabilitas dan durabilitas, sehingga sama seperti Lefebvre, la menyatakan arsitektur kini dapat dipandang sebagai sebuah entitas yang lemah, dengan sifat yang temporal/monumental serta tidak terprediksi, meninggalkan pandangan lama yang menyorot arsitektur sebagai suatu rangkaian struktur yang kaku baik secara fisik maupun pemrograman ruang yang terjadi di dalamnya.

Berbeda dengan kolektivitas yang terdapat pada arsitektur tradisional yang hadir dalam masyarakat homogen, weak architecture yang dikedepankan oleh Rubio berusaha membawa kolektivitas ruang tersebut dalam konteks masyarakat modern yang heterogen. Ruang dan waktu dalam konteks perkotaan berjalan secara heterokonik, oleh karena itu dibutuhkan pendekatan yang mampu mewadahi dan mempertemukan berbagai arahan yang berbeda menjadi suatu kesatuan yang bersifat kolektif (Rubio, 1987).

Secara terpisah, konsep weak architecture juga diusung oleh arsitek Jepang Sou Fujimoto. Dalam pandangannya, Fujimoto tak lagi memandang arsitektur sebagai suatu tatanan yang mengatur secara keseluruhan segala elemen yang terdapat di dalamnya, melainkan melalui relasi antar fragmen-fragmen yang terjadi secara spontan (Fujimoto, 2008). Arsitektur bukan lagi sebuah tatanan yang bersifat absolut, melainkan tatanan yang tersusun atas ketidakberaturan yang terjadi di dalamnya. Untuk memahami pandangan Fujimoto secara lebih jauh, kita pun menilik kembali akan terbentuknya konsepsi makna akan ruang pada gua sebagai tempat pernaungan, serta lahirnya sarang ataupun arsitektur sebagai upaya rekonstruksi akan ruang melalui representasi mental atas konsepsi makna tersebut, yang diidentifikasi melalui istilah cave dan nest.

Dalam sebuah gua, segala komponen dan elemen yang menyusun ruang yang terbentuk telah terbentuk terlebih dahulu untuk kemudia dihuni dan diisi oleh manusia beserta aktivitasnya. Setiap elemen tidak terkait akan fungsi secara spesifik sehingga interaksi antar manusia dengan objek-objek disekitarnya bersifat spekulatif dan spontan, memungkinkan terjadinya interpretasi 
penggunaan secara tak terbatas dalam ruang dan waktu yang berbeda. Secara kontradiktif, elemen-elemen yang menyusun sebuah sarang disesuaikan dengan kebutuhan dan kenyamanan sang penghuni. Segala objek dan komponen yang terdapat di dalam sarang tersebut seolah mensugestikan terlebih dahulu akan bagaimana dirinya dapat digunakan oleh manusia, serta terikat akan fungsi-fungsi tertentu secara spesifik.
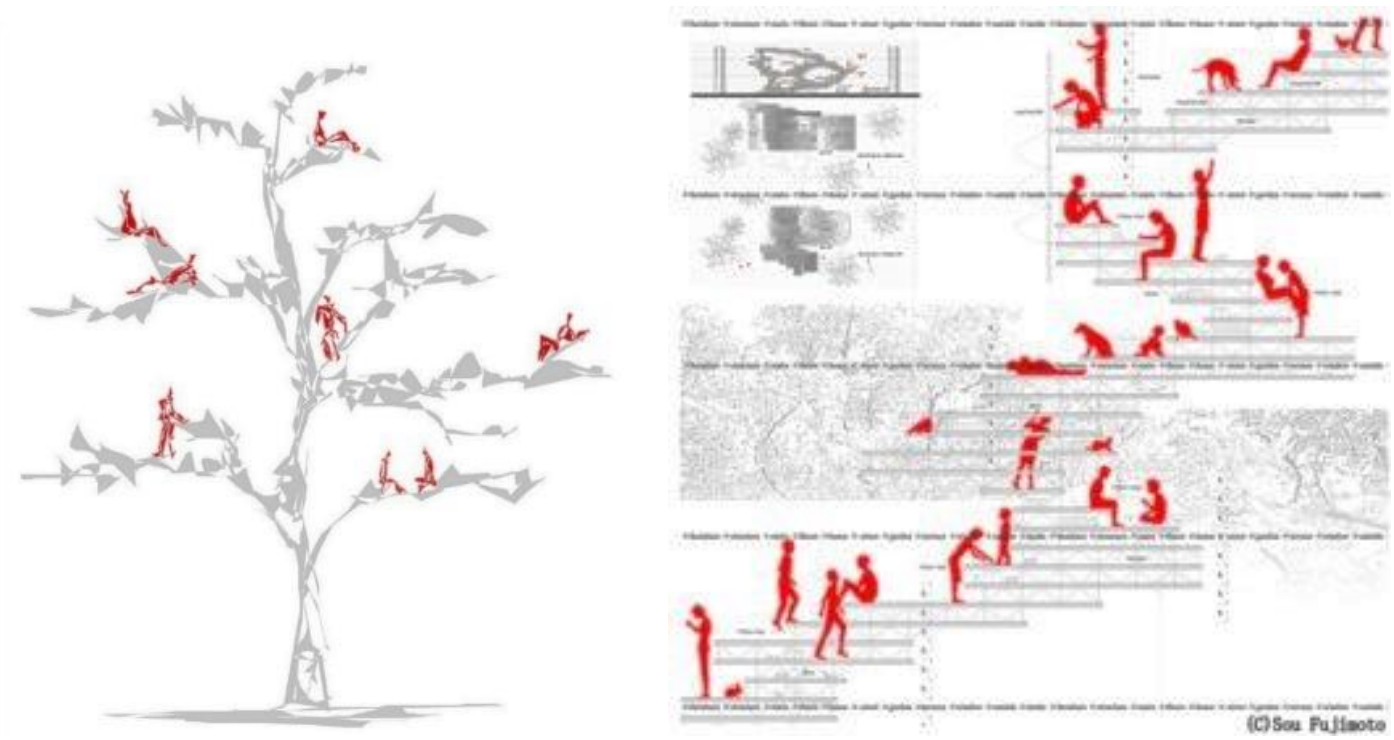

Gambar 2. Interaksi antar manusia dengan elemen pada lingkungan sekitarnya Sumber: iaacblog.com, diunduh 2 September 2019

Terbentuknya ruang yang identik dengan sifat-sifat abstrak dan monumental seperti dikemukakan oleh Lefebvre, Rubio, dan Fujimoto muncul secara inklusif pada berbagai masyarakat yang berbeda, termasuk dalam budaya lokal Indonesia. Ruang-ruang kolektif yang digunakan secara bersama-sama dalam arsitektur tradisional di Indonesia pada hakikatnya bukanlah suatu wadah yang diisi oleh objek dan simbol yang mensugestikan fungsi ataupun aktivitas yang dapat dilakukan oleh pemakainya. Sebaliknya, la cenderung hadir dalam wujud suatu kekosongan, sebuah jeda yang mengintervensi rangkaian aktivitas dan mengorientasikan seluruh fungsi yang ada disekitarnya. (Badan Ekonomi Kreatif Indonesia, 2017) Selayaknya ruang yang monumental, la membuka berbagai kemungkinan untuk terjadi di dalamnya.

Jakarta tak ubahnya sebuah kampung raksasa, sebuah organisme akbar. Sebagai ibukota negara, budaya sosial masyarakat Indonesia yang terbiasa hidup dengan kultur lisan dan gotong royong pun terakumulasi dalamnya. Maka tak ayal, ditengah problematika akan privatisasi dan kegagalan ruang publik dalam mewadahi penghuninya, masyarakat pun menterjemahkan pemahaman mereka akan budaya spasial dalam bentuk ruang kolektif di tengah padatnya kawasan perkotaan.

Ruang kolektif tersebut pada umumnya hadir secara informal di antara pusat aktivitas masyarakat, dalam rupa warung, kios pedagang kaki lima, hingga pasar malam. Layaknya ruang representasi dalam bayangan Lefebvre ataupun weak architecture gagasan Rubio dan Fujimoto, ruang-ruang kolektif perkotaan tersebut memiliki sifat temporal, bersikap fleksibel terhadap dimensi waktu dan ruang, namun tanpa kehadiran fisik pun mereka tetap dapat dirasakan melalui memori para manusia yang terlibat di dalamnya. la juga tak direncanakan, dengan cair dan spontan mengisi ruang-ruang antara seperti trotoar pejalan kaki, gang yang diapit oleh padatnya kawasan perkotaan, hingga naungan bayangan pepohonan di tepi taman. Negosiasi spasial pun dilakukan untuk menentukan batas-batas ruang yang terbentuk, serupa dengan manusia yang dengan kepekaannya akan ruang disekitarnya mengisi gua secara spontan. Sebagai third place yang menyediakan ruang-ruang tanpa batas yang menerima seluruh lapisan masyarakat kota serta menghadirkan jeda di antara rutinitas keseharian. 
Bila ruang representasi dan weak architecture terkait erat dengan pengalaman dan persepsi masing-masing individu akan suatu ruang, akumulasi dari memori kolektif individu-individu yang muncul dari sebuah ruang publik pun hadir memanifestasikan dirinya dalam wujud third place. Serupa dengan ruang representasi dalam triade Lefebvre, nilai-nilai temporal dan monumental mendefinisikan karakteristik third place hingga la dapat menjalankan perannya sebagai ruang di antara first place (rumah) dan second place (tempat bekerja), suatu jeda yang menjadi pusat aktivitas informal yang menghembuskan nafas kehidupan bagi suatu komunitas masyarakat. Dalam buku The Great Good Place, Ray Oldenburg, menjabarkan bahwa suatu tempat dapat dikatakan sebagai third place kala la memiliki karakteristik mampu mengakomodir pengalamanpengalaman personal serta kebutuhan dari setiap penggunanya, menghadirkan suatu ruang dengan karakteristik berbeda dari rumah dan tempat kerja, mendefinidisikan jati diri setiap individu, fungsional bagi komunitasnya, serta selalu hadir kala dibutuhkan. (Oldenburg, 1989)

Berbeda dengan rumah dan tempat kerja yang memiliki karakteristik terstruktur, hierarkis, dan formal, third place merupakan wadah bagi komunitas untuk berekspresi secara bebas dengan setara tanpa adanya perbedaan antar individu. Suatu ruang bagi masyarakat untuk saling bercengkrama, bermain, dan melepas jenuh dari rutinitas sehari-hari. Namun sayangnya, sebagian besar ruang-ruang bagi komunitas yang tersedia khsususnya dalam kota-kota besar seperti Jakarta belum mampu mengimplementasikan kualitas-kualitas yang dimiliki oleh sebuah third place secara penuh. Ruang publik pada umumnya lebih diperlakukan sebagai ruang sisa yang memiliki jarak dengan manusia yang menghuninya. Pembentukan monitu atau rekoleksi memori tidak menjadi pertimbangan dalam mengolah ataupun meregulasikan ruang publik tersebut hingga pada akhirnya, la pun dipandang tak lebih dari sekedar ruang negatif yang tidak hidup.

Di lain sisi, pendekatan-pendekatan bersifat institusional kerap mendominasi dalam perencanaan serta perancangan ruang publik. Pemerintah, urban planner, maupun arsitek hadir sebagai figur dominan yang memetakan struktur dari suatu ruang publik yang tak jarang mengesampingkan nilai-nilai spontanitas dan temporal yang dibutuhkan untuk memberikan nyawa bagi suatu third place. Sebagai alternatif, publik pun disajikan jajaran pusat perbelanjaan yang tentunya ditujukan secara eksklusif bagi lapisan masyarakat tertentu. Dengan struktur spasial dan pemrograman yang direncanakan berfokus pada nilai komersial, pada akhirnya tak ada lagi ruang bagi aktivitas informal untuk terjadi didalamnya dengan segala batasan yang muncul.

Sebagai mana masyarakat kota mengisi ruang-ruang negatif dalam wajah kota dan menghidupinya melalui memori kolektif, dalam perancangan ruang publik sebagai third place, kita perlu melihat manusia bukan sebagai objek pasif melainkan sebagai nyawa bagi ruang yang terbentuk, menciptakan ketidakmenentuan yang spekulatif dan menghadirkan berbagai kemungkinan baru dalam tatanan yang terbentuk. Arsitektur bukan lagi sebagai suatu sarana institusional yang mengatur kehidupan manusia melainkan wadah yang cair dan mengangkat taraf hidup manusia yang telah ada sebelumnya.

Terlepas dari perannya sebagai ruang kolektif bagi publik di tengah kawasan perkotaan, third place pun menggemban peranan ganda sebagai lanskap kreatif yang menunjang perkembangan perekonomian kota. Seperti dibahas sebelumnya oleh Richard Florida dalam bukunya, The Rise of Creative Class, abad ke-21 menjadi tonggak revolusi sosial-ekonomi masyarakat perkotaan yang bilamana revolusi industri menciptakan kecenderungan kota sebagai perwujudan fisik dari tren efisiensi dan produktivitas, maka revolusi digital di akhir abad ke-20 mengubah paradigma tersebut dan menjadikan kota sebagai titik temu yang penuh akan keberagaman dan otentisitas bagi para insan kreatif (Florida, 2012). Layaknya third place menjadi ruang sosial yang menginisiasi interaksi antar manusia yang menghuninya, sebagai lanskap kreatif la mampu mengangkat interaksi sebagai wadah bagi pertukaran ide dan katalis perkembangan sosialekonomi dalam suatu kawasan perkotaan.

Serupa dengan konsepsi atas third place sebagai ruang kolektif dalam kawasan perkotaan yang menghadirkan sifat-sifat monumental, temporal, dan spontan dalam konteks ruang waktu 
yang telah menjadi cair, Florida pun turut mengemukakan empat prinsip yang mengandung nilai-nilai tersebut sebagai syarat bagi suatu ruang untuk dapat berperan sebagai lanskap kreatif bagi masyarakat perkotaan, yakni keberagaman (diversity), fleksibilitas/pilihan (choice), otentitas (authenticity), dan konektivitas (connectivity).

Keberagaman (diversity) menandakan heterogenitas penduduk beserta kekayaan variasi dalam berbagai aspek kehidupan diantarnya fungsi dan aktivitas yang terdapat dalam suatu kawasan perkotaan, menciptakan peluang akan munculnya ide-ide baru melalui pertukaran berbagai paradigma yang berbeda. Fleksibilitas pilihan (choice) menunjukkan kebebasan dalam menjalani kehidupan baik pada kegiatan sehari-hari yang sederhana semisal menentukan rute mobilisasi dari rumah ke tempat kerja, hingga pilihan penting seperti menentukan arah karier. Prinsip otentisitas (authenticity) menjadi salah satu aspek terpenting mengingat nyawa dan fungsi suatu lingkungan sebagai pemicu kreativitas bergantung pada keberadaan genius loci yang menghadirkan sense of place sebagai identitas ataupun citra kawasan perkotaan, baik itu berupa kehadiran bangunan bersejarah, permukiman tradisional, hingga pertokoan lokal yang memanifestasikan nilai-nilai tradisi dan kebudayaan sekitar. Koneksi (connection) merupakan indikasi bahwa suatu ruang kota dapat menggemban peran sebagai lanskap kreatif kala la mampu menjadi titik temu yang menghubungkan antar manusia, ide, alam, sejarah, budaya, maupun inspirasi.

Melihat segala potensi yang dimiliki oleh third place baik sebagai ruang kolektif publik maupun lanskap kreatif bagi masyarakat perkotaan, maka muncul suatu urgensi untuk mengidentifikasi nilai-nilai kolektif dan citra kawasan dalam perancangan arsitektur sebagai wadah sosial sehingga pada akhirnya bangunan tak hanya menyediakan ruang semata, melainkan juga membuka berbagai kemungkinan melalui segala aktivitas dan interaksi yang terjadi di dalamnya.

\section{METODE}

Secara prinsip, perencanaan proyek Ruang Kolektif Kebon Kacang didasari oleh investigasi tapak yang berfokus pada konteks kampung kota sebagai third place selaku pedoman utama dalam mengidentifikasi permasalahan dan kebutuhan yang terdapat pada kawasan. Materi dan data, yang digunakan dalam proses analisis kawasan hingga mendapatkan produk sintesis berupa gagasan dan skema perancangan, dilandasi oleh metode penelitian berupa kajian pustaka dan pengamatan lapangan.

Langkah pertama penelitian ialah mencari materi pendukung melalui kajian pustaka sebagai landasan bagi tahapan-tahapan analisis beserta sintesis yang dilaksanakan setelahnya. Secara garis besar, teori yang diangkat bersumber dari empat pustaka utama, yakni produksi ruang sosial (Lefebvre, 1974), teori weak architecture (Rubio, 1987) (Fujimoto, 2008), dan prinsip pembentukan place sebagai lanskap ekonomi kreatif (Florida, 2012).

Keempat teori tersebut menjadi dasar dalam mengidentifikasi fenomena pembentukan ruang sosial (Lefebvre, 1974) (Rubio, 1987) (Fujimoto, 2008), serta karakteristik kawasan (Florida, 2012) yang terjadi pada kelurahan Kebon Kacang dan kemudian menjadi fokus utama dalam langkah kedua yaitu observasi melalui pengamatan lapangan. Dalam ruang lingkup pengamatan radius 500 meter dengan Jalan Kebon Kacang Raya sebagai titik pusat aktivtias publik yang menghubungkan kawasan hunian berkepadatan tinggi di kelurahan Kebon Kacang dengan sentra bisnis Thamrin serta pasar Tanah Abang, ditemukan bahwa ruang sosial timbul secara dominan sepanjang jalan kolektor pada kelurahan seperti Jl. Kebon Kacang Raya dan Jl. Kebon Kacang IX sebagai rute mobilisasi utama bagi pejalan kaki di antara first place (hunian) dan second place (tempat kerja).

Setelah identifikasi citra dan potensi kawasan telah berhasil dilakukan, langkah ketiga mencakup sintesis yang mentransformasikan data yang didapat dari langkah-langkah sebelumnya menjadi suatu gagasan perancangan yang menyeluruh berupa komposisi ruang, elemen arsitektural, hingga pemrograman pada bangunan sebagai akumulasi atas kajian teoritis terhadap hasil investigasi kawasan kampung kota Kebon Kacang. 


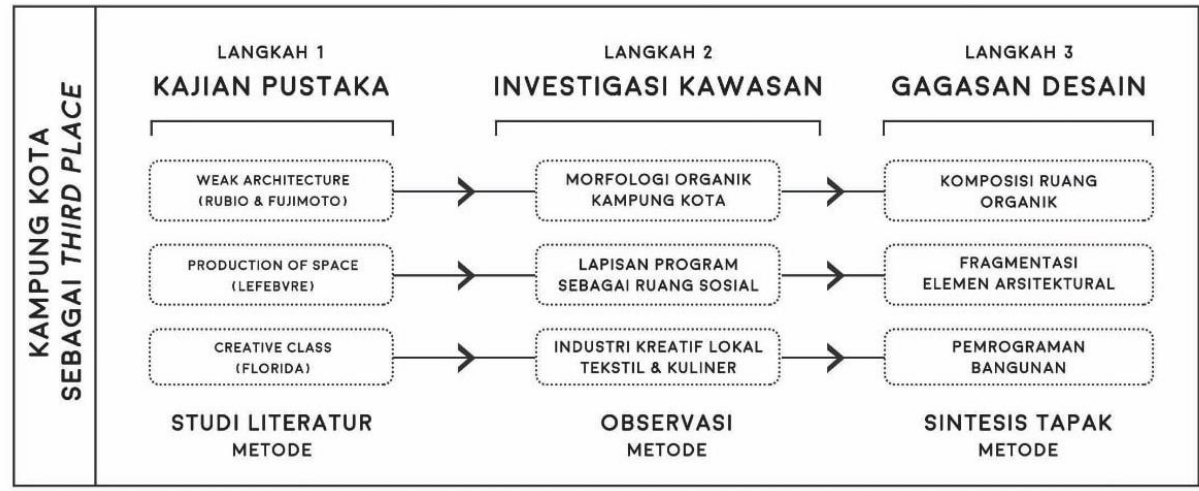

Gambar 3. Kerangka metode penelitian sebagai dasar perencanaan proyek Sumber: Penulis, 2019

\section{DISKUSI DAN HASIL}

Secara morfologis, urban fabric kawasan Kebon Kacang memiliki bentukan organik dikarenakan sejarah kawasan tersebut sebagai area perkampungan bagi para pendatang yang pada awalnya menetap di sekitar pasar Tanah Abang tanpa adanya campur tangan pemerintah ataupun tuan tanah besar dalam penataan kawasan. Secara makro, fisik dan fungsi kawasan pada kelurahan Kebong Kacang terbagi dua oleh jalan arteri KH. Mas Mansyur, yakni sebelah Timur yang didominasi oleh hunian, dan sebelah Baratnya yang sebagian besar berupa pusat perekonomian pasar Tanah Abang.
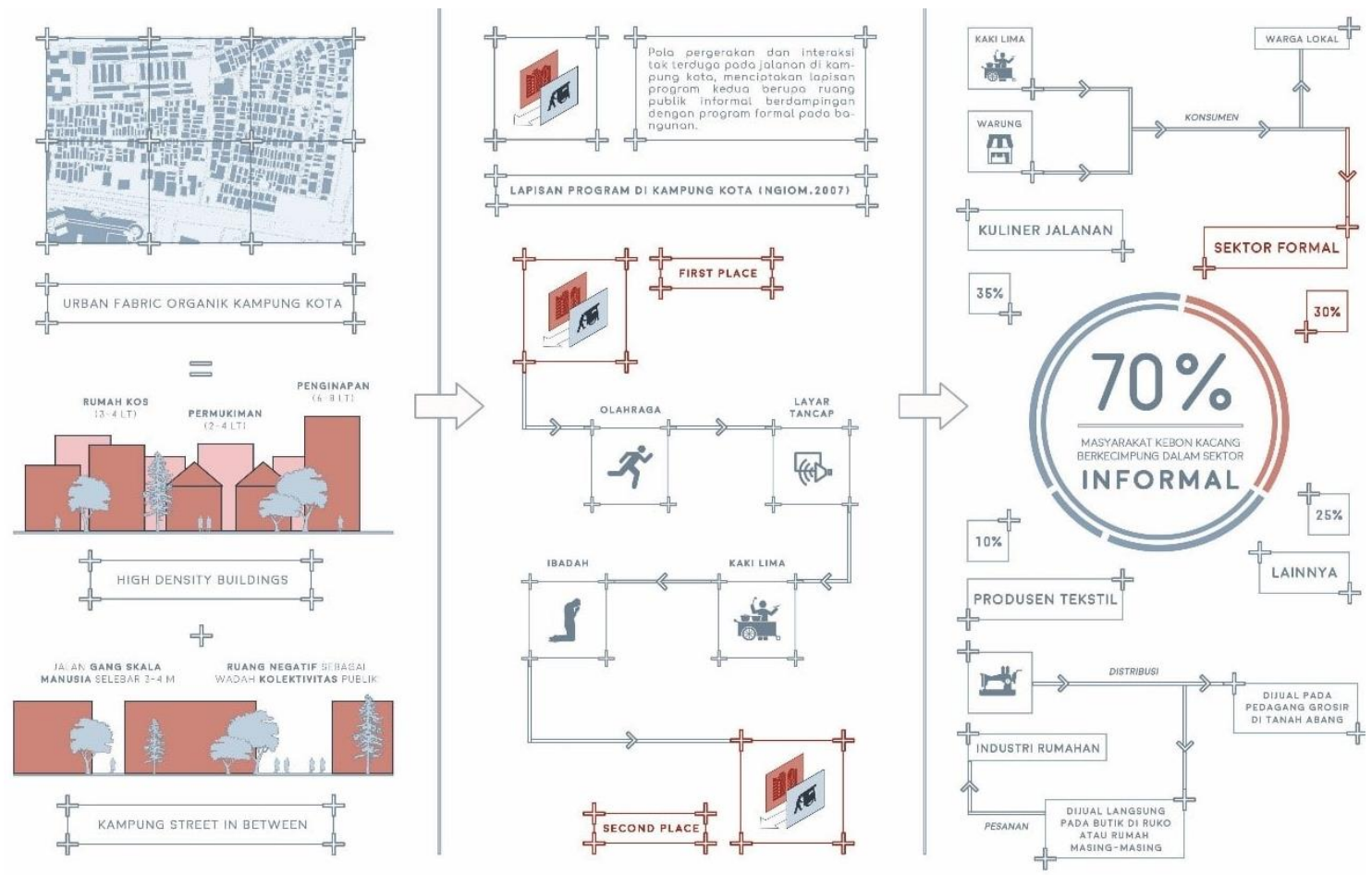

Gambar 4. Sintesis kawasan Kebon Kacang

Sumber: Penulis, 2019

Pada bagian Timur Jl. KH. Mas Mansyur hingga Kali Cideng, hunian yang juga difungsikan sebagai rumah kos ataupun penginapan setinggi 3-4 lantai banyak ditemukan mengapit gang ataupun jalan lingkungan selebar 3-5 meter yang menjadi ciri khas fisik kawasan, sedangkan jalan kolektor selebar 6-8 meter didominasi oleh hotel-hotel setinggi 6-12 lantai dan bangunan ruko yang menunjang aktivitas komersial pada kawasan hunian disekitarnya. Ruang terbuka 
hijau dengan luasan cukup signifikan terdapat pada Jl. Kebon Kacang IX, namun sebagai lahan milik swasta yang belum dikembangkan sehingga tidak memberikan dampak bagi aktivitas masyarakat disekitarnya. Bagian Barat JI. KH. Mas Mansyur hingga Kali Ciliwung didominasi oleh pusat aktivitas komersial pasar Tanah Abang pada bagian yang berbatasan langsung dengan Jl. Kebon Jati Raya dan JI. KH. Mas Mansyur sendiri, mengapit kawasan hunian berkepadatan tinggi dengan fungsi campuran komersial.

Selain ruang positif berupa bangunan, urban fabric kawasan Kebon Kacang juga tersusun atas ruang negatif berupa jalanan sebagai jalur pergerakan sekaligus ruang sosial bagi masyarakatnya. Selayaknya dikemukakan oleh Ngiom, aktivitas dalam perkotaan di kawasan Asia Tenggara pada umumnya terjadi dalam dua lapisan (layer), yakni lapisan bawah di mana bentukan fisik berupa bangunan mewadahi aktivitas formal yang bersifat permanen, dan lapisan diatasnya di mana masyarakat kota berinteraksi secara temporal dan cair dalam fenomena keruangan berupa pasar tumpah, warung, dan pedagang kaki lima yang membentuk memori kolektif dari kebudayaan masyarakatnya (Ngiom, 2007). la menganalogikan kombinasi ruang yang terbentuk seperti kue lapis di mana fungsi yang terdapat pada kedua lapisan tersebut saling menunjang, menciptakan dialog antara yang formal dengan informal, dalam bentuk bangunan dan ruang terbuka yang berada diantaranya.

Dengan densitas bangunan maupun manusia yang tinggi beserta letak kawasan Kebon Kacang sebagai kawasan hunian yang berdekatan salah satu pusat pereknomian serta sentra bisnsis terbesar di kota Jakarta menciptakan suatu fenomena khas di mana potensi kawasan yang ada menggundang munculnya aktivitas informal yang mengisi titik-titik transisi seperti jalur pergerakan, serta perimeter dari pusat aktivitas kawasan. Peluang munculnya aktivtias informal tersebut juga diperkuat oleh morfologi kawasan Kebon Kacang sebagai kawasan hunian dan perdagangan yang terbentuk secara organik, menghasilkan ruang-ruang antara yang tak terduga dan kemudian diisi secara spontan hingga pada akhirnya menciptakan suatu bentukan yang bersifat temporal dan monumental sebagai wadah aktivitas yang dapat dinikmati seluruh kalangan yang terlibat di dalamnya.

Secara nyata, contoh pemanfaatan ruang antara yang cukup dominan pada kawasan Kebon Kacang ialah pedagang kaki lima yang mengisi jalur pergerakan utama pada kawasan seperti pada JI. Kebon Kacang Raya dan Jl. Kebon Kacang IX yang menghubungkan kawasan hunian di Kebon Kacang dengan pusat bisnis dan perbelanjaan di kawasan $\mathrm{MH}$. Thamrin. Lalu lalang masyarakat warga sekitar hingga para pekerja kantoran di kawasan tersebut mengundang aktivitas pedagang kaki lima yang menyediakan berbagai jajanan kuliner hingga komoditaskomditas sederhana pada sepanjang bahu jalan. Ruang-ruang sisa di sepanjang sisi jalanan diubah sebagai tempat bagi para pedagang untuk menjajakan kiosnya sekaligus sebagai tempat duduk-duduk bagi para pelanggan yang makan sembari bersosialisasi.

Keberadaan lanskap kreatif di Kawasan Kebon Kacang pada hakikatnya terbentuk akibat pencampuran fungsi rumah sebagai tempat tinggal sekaligus ruang usaha ataupun produksi yang menunjang aktivitas perekonomian di sekitarnya. Tercatat $70 \%$ dari masyarakat yang tinggal pada kawasan Kebon Kacang memilih untuk menggantungkan mata pencahariannya pada sektor informal yang dijalankan dalam rumah mereka ataupun kawasan sekitarnya, yakni dengan rincian $51 \%$ dalam bisnis perdagangan kecil seperti warung ataupun kios kaki lima, 15\% manufaktur khususnya dalam industri tekstil rumahan, $21 \%$ jasa, dan $13 \%$ lainnya (Tarumanagara, 2012). Untuk menganalisis pembentukan fungsi campuran tersebut beserta aktivitas yang terdapat didalamnya, kita perlu terlebih dahulu memahami kaitan antara kawasan permukiman pada kelurahan Kebon Kacang dengan sentra bisnis Thamrin dan pasar Tanah Abang.

Bilamana warung-warung yang terdapat pada bagian depan rumah warga hadir dalam rangka memenuhi kebutuhan pangan bagi para karyawan yang bekerja di perkantoran kawasan Thamrin dan penduduk permukiman Kebon Kacang sendiri, seperti telah dibahas sebelumnya, keberadaan industri tekstil rumahan muncul untuk menunjang aktivitas perekonomian di pasar Tanah Abang dengan menghasilkan produk jadi berupa pakaian ataupun kain yang siap dijual di 
pasar tersebut. Pada umumnya, industri tekstil rumahan yang terbentuk berupa partai kecil dengan modal dibawah tiga juta rupiah per bulannya yang menghasilkan produk jadi untuk dijual dengan harga lebih murah kepada para pedagang partai besar di pasar Tanah Abang, namun terdapat pula beberapa produsen yang memilih untuk mendirikan galeri busana pada rumahrumah mereka. Kehadiran usaha kecil menengah lokal yang diinisiasi masyarakatnya sendiri mengindikasikan pemenuhan prinsip kawasan sebagai lanskap kreatif seperti yang dikemukakan oleh Richard Florida terkait otentisitas (authenticity) sebagai citra suatu kawasan (Florida, 2012).

Karakteristik kawasan Kebon Kacang yang telah dibahas di atas, baik secara fisik melalui morfologi kawasannya maupun non-fisik yang diwujudkan melalui aktivitas penghuni dan program informal yang terbentuk dalam ruang antara, dikembangkan sebagai titik awal dalam gagasan perancangan ruang kolektif sebagai lanskap kreatif bagi masyarakat Kebon Kacang. Perancangan proyek Ruang Kolektif Kebon Kacang ditujukan sebagai jawaban atas permasalahan akan kurangnya third place sebagai wadah kolektivitas masyarakat di kawasan tersebut. Menanggapi konteks kawasan Kebon Kacang sebagai permukiman kampung kota berkepadatan tinggi yang menggandung nilai-nilai keberagaman, maka diharapkan arsitektur yang terbentuk mampu berperan tak hanya sebagai wadah interaksi, melainkan juga sarana kreasi dan promosi bagi identitas lokal masyarakat Kebon Kacang. Elemen-elemen pembentuk ruang yang terdapat pada kawasan Kebon Kacang pun diadopsi sebagai landasan bagi perancangan arsitektur yang terwujud.
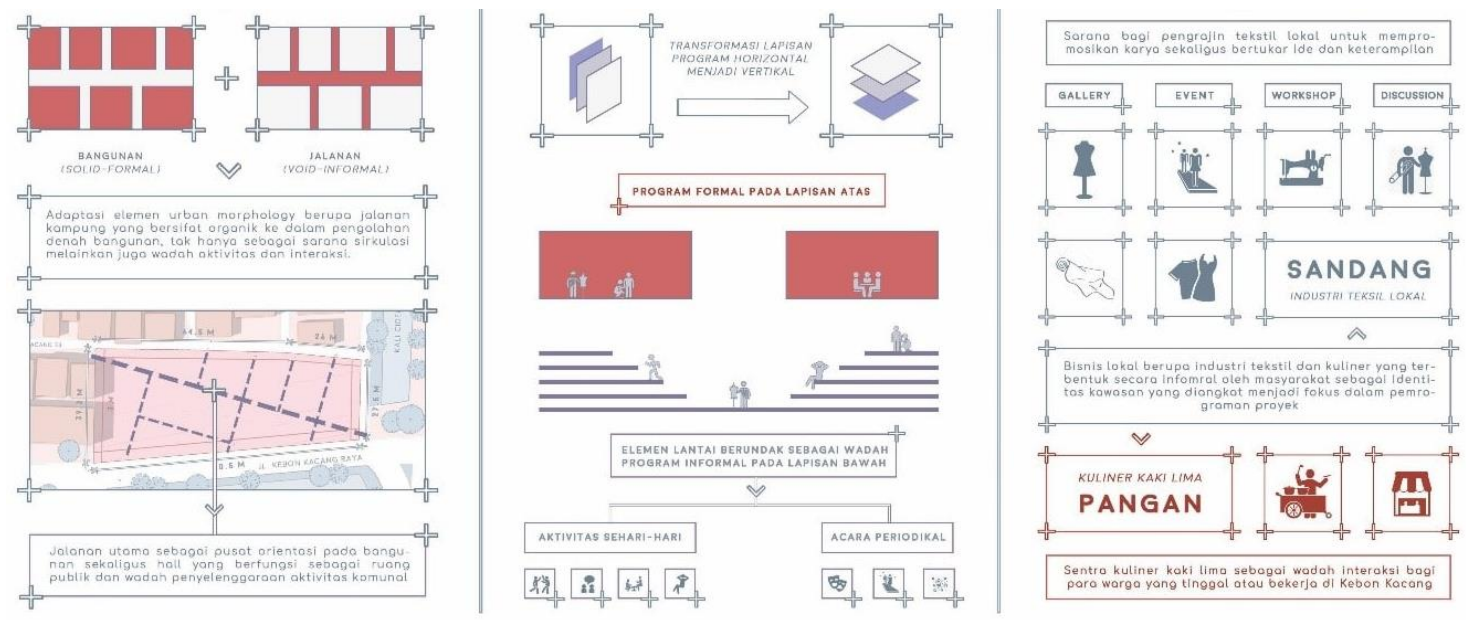

Gambar 5. Gagasan perancangan yang berlandaskan konteks fisik dan non-fisik kawasan pada proyek Ruang Kolektif Kebon Kacang

Sumber: Penulis, 2019

Sebagai dasar bagi komposisi ruang, elemen jalanan yang mendefinisikan bentukan organik pada kampung kota diadaptasi sebagai datum yang mengorganisasikan denah pada bangunan. Bentukan negatif berupa void dihadirkan dalam rangka menggantikan bentukan padat bangunan yang mengapit jalanan, menjadikannya sebagai ruang positif yang bersifat transparan dan inklusif, tak hanya berperan sebagai jalur sirkulasi melainkan juga wadah interaksi dan rekreasi masyarakat sekitarnya. Selayaknya disebutkan oleh Rubio, jalanan yang dikelilingi oleh elemen arsitektural void menghilangkan kesan formal dan stabil pada bangunan sehingga mampu menggundang terjadinya aktivitas informal yang spontan dan temporal melalui interaksinya dengan masyarakat di pusat kota yang bersifat heterogen (Rubio, 1987).

Ruang kolektif yang inklusif terbentuk melalui elemen arsitektural yang bersifat ambigu sehingga menggundang multitafsir bagi berbagai pemakai yang berbeda. Makna dan fungsi tidak dikunci oleh arsitek sebagai perancang sehingga pada akhirnya mengizinkan pengguna dari seluruh kalangan dan lapisan masyarakat yang beragam. Elemen lantai difragmentasikan menjadi lapisan berundak yang disusun secara vertikal, merepresentasikan lapisan program 
yang terjadi dalam kampung kota (Ngiom, 2007) dan mentrasnformasinya sehingga mampu beradaptasi dengan konteks densitas tinggi perkotaan sekaligus memiliki fleksibilitas fungsional dalam mewadahi aktivitas keseharian maupun acara periodikal yang terjadi.

Secara garis besar, terdapat dua program utama yang direncanakan yakni berfokus pada dua komoditas lokal berupa sandang dan pangan dengan kateogri commercial dan hospitality. Program utama sandang berupa galeri sebagai ruang interaksi dan kreasi bagi para insan kreatif, baik para masyarakat lokal pelaku industri tekstil maupun para pekerja dan tamu yang datang dari sekitar kawasan untuk menikmati hasil karya tekstil di Kebon Kacang. Aktivitas tersebut didukung melalui fungsi-fungsi lainnya seperti lokakarya, pagelaran busana, hingga pameran yang turut berperan sebagai wadah kreativitas serta katalis sosial-ekonomi bagi masyarakat.

Program pangan merupakan substitusi dan penataan kembali atas pedagang kaki lima dan warung makanan yang telah ada sebelumnya di sekitar tapak sebagai potensi third place pada kawasan yang menggundang berkumpulnya para masyarakat kota yang beraktivitas di sekitar kawasan Kebon Kacang dan menciptakan dialog antara bangunan yang bersifat informal dengan pusat perbelanjaan di sekitarnya yang bersifat formal. Keberadaan kedua program utama bersifat komplementer dengan kehadiran program pangan menggundang kehadiran massa dalam jumlah besar untuk saling berinteraksi dan turut berpartisipasi dalam perkembangan ekonomi kreatif yang dijalankan pada program sandang.

Pembagian zonasi ruang pada Ruang Kolektif Kebon Kacang didasari oleh tiga fungsi utama pada bangunan sesuai yang dipaparkan dalam tujuan proyek, yakni third place sebagai wadah kreasi, interaksi, serta promosi dalam menunjang ekonomi kreatif di Kawasan Kebon Kacang. Zona Kreasi berisi ruang-ruang yang ditujukan sebagai sarana pengembangan produk-produk kreatif lokal, ditujukan bagi para insan kreatif, dan bersifat semi-publik seperti fashion studio, upcycling center, perpustakaan, ruang diskusi, dan ruang arsip. Zona promosi berisi ruang galeri luas yang digunakan untuk memperagakan dan memfasilitasi pameran produk lokal khususnya berupa busana. Zona Interaksi mencakup ruang-ruang yang berfungsi sebagai fasilitas publik di mana seluruh lapisan masyarakat dapat menghabiskan waktu luangnya sembari bersosialisasi seperti plaza, sentra kuliner, dan lobby, juga sebagai penghubung antara dua zona lainnya. Fungsi-fungsi tersebut diterjemahkan sebagai tiga zona utama dalam bangunan yang ditunjang oleh zona keempat, yakni servis sebagai penunjang aktivitas yang terjadi didalamnya.

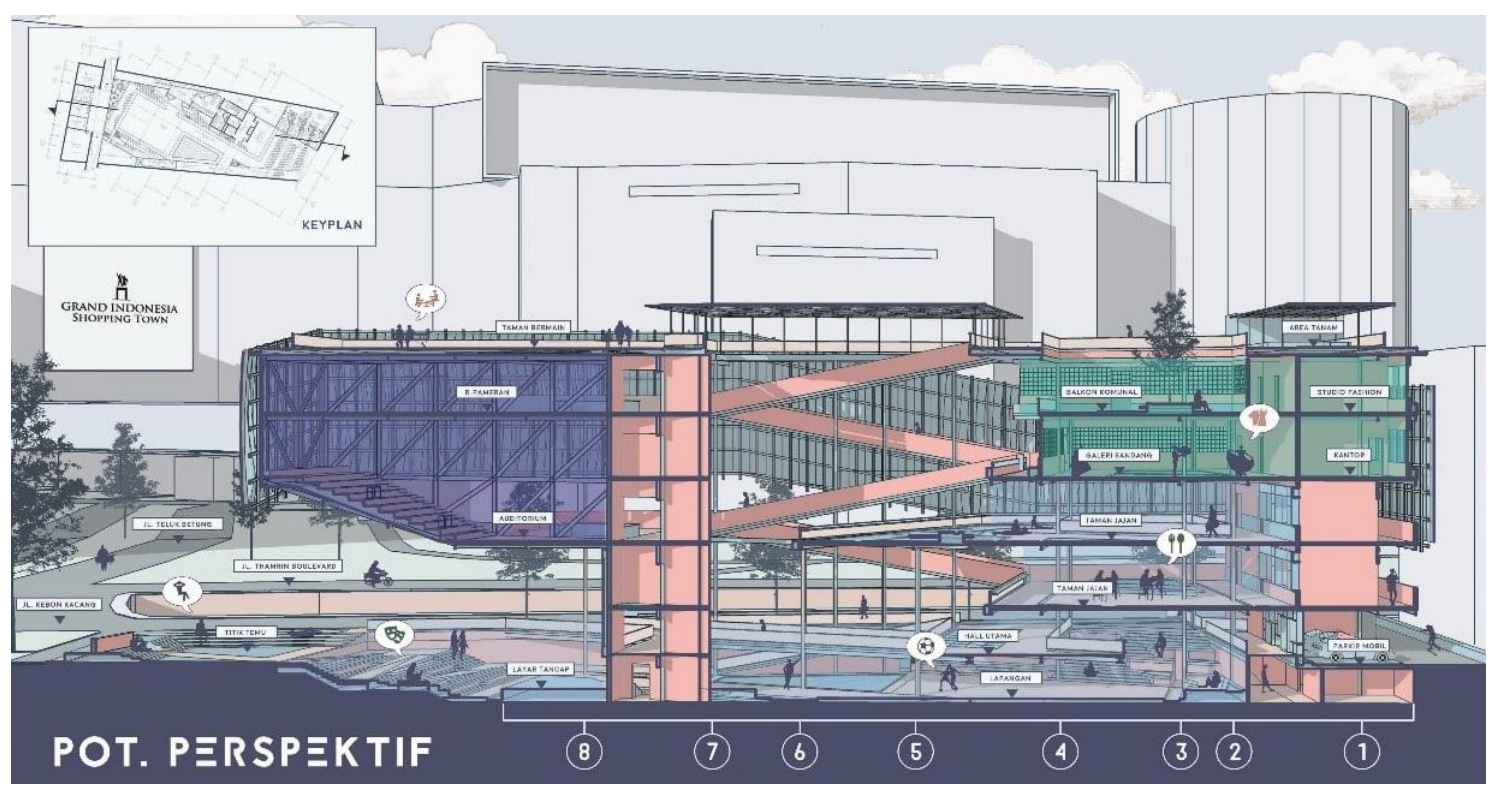

Gambar 6. Tiga fungsi utama bangunan pada zona interaksi (biru muda), zona kreasi (hijau), dan zona promosi (biru tua) yang ditunjang oleh zona servis (merah)

Sumber: Penulis, 2019 
Tabel 1. Skema perancangan pada proyek Ruang Kolektif Kebon Kacang

\begin{tabular}{|c|c|c|}
\hline Skema Perancangan & Ilustrasi Diagramatik & Keterangan \\
\hline $\begin{array}{l}\text { Ekstensi Urban } \\
\text { Fabric Kawasan }\end{array}$ & & $\begin{array}{l}\text { Bentukan denah bangunan } \\
\text { mengadopsi tipologi gang } \\
\text { kampung untuk menciptakan } \\
\text { ruang-ruang komunal yang cair } \\
\text { sekaligus menghubungkan } \\
\text { aktivitas dan pergerakan } \\
\text { manusia di sekitarnya }\end{array}$ \\
\hline $\begin{array}{c}\text { Orientasi dan } \\
\text { Pencapaian }\end{array}$ & & $\begin{array}{l}\text { Orientasi denah bangunan } \\
\text { dimiringkan sehingga } \\
\text { membentuk sumbu yang } \\
\text { menghubungkannya dengan } \\
\text { Bundaran Hotel Indonesia } \\
\text { sekaligus menciptakan } \\
\text { pencapaian yang mengundang } \\
\text { terhadap perempatan di depan } \\
\text { tapak }\end{array}$ \\
\hline
\end{tabular}

Basement sebagai
Ruang Publik

Area publik utama diturunkan sehingga menjadi lantai semibasement guna menghindari hiruk pikuk perkotaan sekaligus wadah cross program antar berbagai aktivitas yang berbeda mulai dari senam bersama hingga pagelaran busana

Sirkulasi Ramp

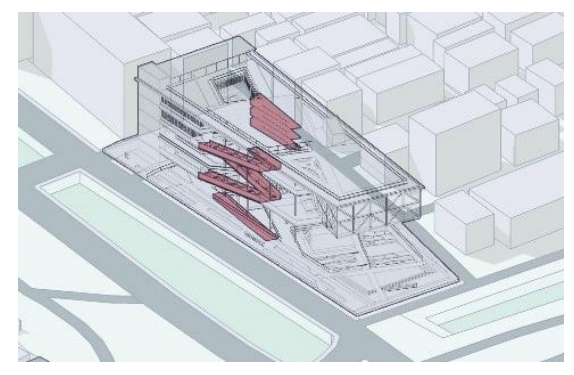

Solid-void

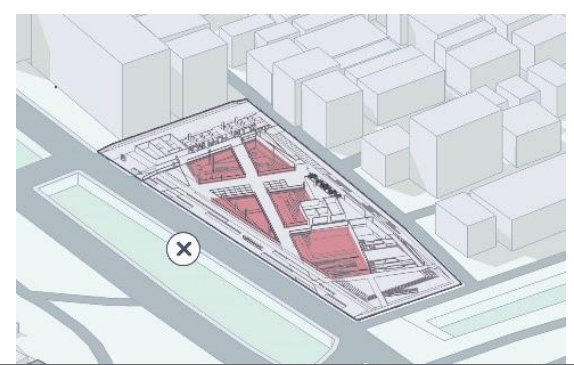

Pengunaan ramp yang difungsikan sebagai area komunal sekaligus sirkulasi utama mengaburkan batasbatas antar lantai berbeda dan menciptakan kemenerusan pergerakan dalam bangunan secara halus

Void yang mengapit ruang aktivitas dan sirkulasi pada bangunan berfungsi mengubah persepsi akan densitas tinggi kawasan sekaligus menciptakan keterkaitan visual antar lantai bangunan dan penghawaan alami 


\begin{tabular}{cll}
\hline Skema Perancangan & Ilustrasi Diagramatik & Keterangan \\
\hline $\begin{array}{l}\text { Lapisan Ruang } \\
\text { Komunal }\end{array}$ & $\begin{array}{l}\text { Konsep lapisan aktivitas pada } \\
\text { kampung kota diterjemahkan } \\
\text { melalui fragmentasi elemen } \\
\text { lantai menjadi undakan- } \\
\text { undakan yang menyisipkan } \\
\text { ruang komunal ditengah } \\
\text { sirkulasi antar lantai }\end{array}$ \\
\hline
\end{tabular}

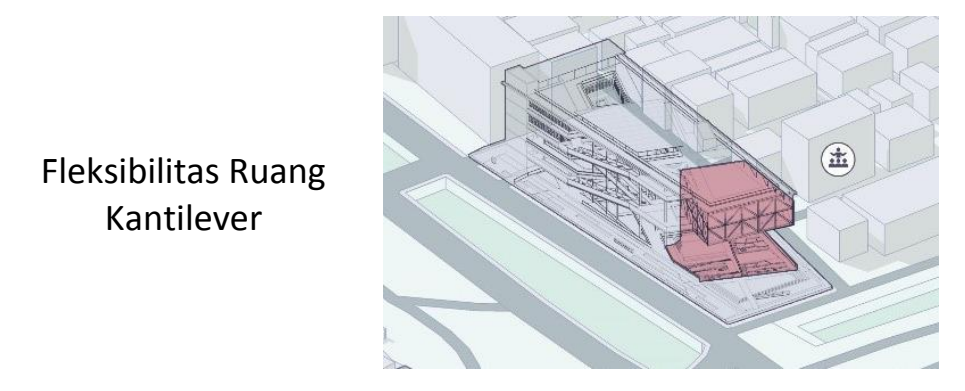

Ruang Pejalan Kaki

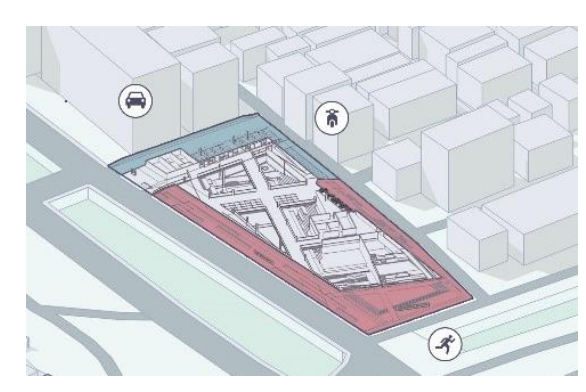

Kehadiran ruang bentang lebar pada kantilever menciptakan wadah informal yang bersifat fleksibel dan menggundang sebagai area komunal berupa teater (It. dasar), auditorium (It. satu), dan galeri (It. tiga)

75\% sisi tapak digunakan sebagai ruang publik yang ramah pejalan kaki dengan parkir kendaraan diletakkan pada sudut belakang bangunan sehingga tidak memotong sirkulasi pejalan kaki

Sumber: Penulis, 2019

\section{KESIMPULAN DAN SARAN}

Melalui analisis dan sintesis pembentukan third place sebagai lanskap kreatif bagi masyarakat di Kelurahan Kebon Kacang, ditemukan tiga poin kesimpulan utama yang menjadi landasan dan gagasan utama bagi perancangan proyek Ruang Kolektif Kebon Kacang, yaitu:

a. Weak architecture selaku metode perancangan yang digunakan dalam mengolah komposisi massa awal yang telah terbentuk.

Sebagai sarana pembentukan ruang sosial yang bersifat cair dan temporal, kehadiran arsitektur dalam proses perancangan melepaskan segala atribut tatanan formal yang dikaitkan kepadanya untuk memberi ruang interpretasi bagi masing-masing individu berbeda dan menciptakan third place yang bersifat publik sekaligus personal sebagai rekoleksi memori dari masyarakat. Metode weak architecture menjadi pedoman utama untuk menghadirkan sifat-sifat tersebut yang dicapai melalui adaptasi elemen jalanan pada kampung kota yang bersifat organik sebagai datum dalam denah bangunan dan menimbulkan kualitas ruang yang ambigu sembari menciptakan tatanan arsitektur unik yang terbentuk melalui ketidakberaturan alih-alih formalitas bentukan massa.

b. Third place sebagai ruang sosial yang terbentuk oleh masyarakatnya sendiri secara informal.

Pemanfaatan ruang-ruang sisa pada kawasan permukiman berkepadatan tinggi membentuk wadah sosial berupa ruang representasi (lived space) yang diinisiasi dan 
dihidupi oleh masyarakat di kawasan Kebon Kacang. Titik-titik di antara pusat aktivitas kawasan tersebut menjadi ruang informal yang befungsi sebagai jeda dalam rutinitas masyarakat perkotaan, selaku third place yang mewadahi kolektivitas manusia dalam lingkungannya. Lantas, alih-alih berlaku sebagai institusi yang menguasai jalannya kehidupan dalam ruang bagi masyarakat tersebut, arsitektur untuk dapat menjadi wadah bagi memori dan kolektivitas masyarakat di sekitarnya pun sebaiknya tidak muncul sebagai buah pemikiran sang arsitek semata, melainkan turut melibatkan masyarakat dan kesehariannya sebagai landasan dalam perancangan third place sebagai ruang sosial. Fragmentasi elemen arsitektur seperti lantai bangunan yang disusun berundak secara vertikal menciptakan ruang arsitektural yang bersifat informal dan ambigu sehingga dapat ditafsirkan secara fleksibel oleh masing-masing penggunanya dan mewadahi jalannya berbagai macam aktivtias yang berbeda.

c. Third place sebagai sarana interaksi, kreasi, dan promosi melalui lanskap kreatif yang dinaunginya.

Menanggapi transformasi perekonomian kota yang mengusung kreativitas manusia sebagai generator utamanya, perancangan third place tak lagi dilihat sebagai sarana interaksi belaka, melainkan juga sarana bagi aktualisasi citra kawasan melalui kreasi dan promosi identitas lokal dengan tiga buah zona fungsi utama, yakni:

a) Zona interaksi sebagai pengemban fungsi utama dari third place sebagai sarana komunal yang dapat diakses oleh seluruh lapisan masyarakat

b) Zona kreasi sebagai wadah bagi para pelaku industri kreatif untuk saling bertukar pikiran dan menuangkan gagasan sebagai generator sosial-ekonomi kawasan

c) Nilai-nilai lokalitas pada kawasan Kebon Kacang ditemukan pada produk lokal yang dihasilkan sektor informal masyarakatnya seperti industri tekstil dan kuliner kaki lima yang kemudian diangkat sebagai program utama dalam zona promosi bangunan

\section{REFERENSI}

Badan Ekonomi Kreatif Indonesia. (2017, December 14). Konsep Indonesia di La Biennale Architettura 2018 Sunyata: The Poetics of Emptiness. Retrieved from bekraf.go.id: http://www.bekraf.go.id/kegiatan/detail/

Florida, R. (2012). The Rise of the Creative Class. New York: Basic Books.

Fujimoto, S. (2008). Primitive Future. Tokyo: Inax Publishing.

Glaeser, E. (2011). Triumph of the City. New York: Penguin.

Jacobs, J. (1989). The Death and Life of Great American Cities. New York: Random House.

Lefebvre, H. (1974). The Production of Space. Oxford: Blackwell.

McGee, T. (1991). The Emergence of Desakota Regions in Asia: Expanding a Hypothesis. Honolulu: University of Hawaii Press.

Michiels, S. (2007). Moving in Between Contrasts. In M. Stani, \& A. van Helmond, Jakarta Megalopolis: Horizontal and vertical observations (pp. 28-56). Amsterdam: Valiz.

Ngiom, L. (2007). Kuala Lumpur - A Thick Crust of Meaning. Architecture Malaysia, 66-69.

Oldenburg, R. (1989). The Great Good Place. Boston: De Capo Press.

Rubio, I.-M. (1987). Weak Architecture. In M. Hays, Architecture Theory Since 1968 (pp. 614623). Cambridge: MIT Press.

Sihombing, A. (2001). Drawing the City: Revealing People's Awareness of Kampungkota Jakarta. International Seminar on Urbanization in the Information Age: New Perspectives on the Transformation of Fast Growing Cities in the Pacific Rim (pp. 6-5). Depok: Universitas Indonesia.

Tarumanagara. (2012). Super Kampung. Jakarta: Jurusan Arsitektur Universitas Tarumanagara. 